TUGAS DASAR ILMU KESEHATAN MASYARAKAT "SEJARAH KESEHATAN MASYARAKAT DAN SEJARAH PUSKESMAS"

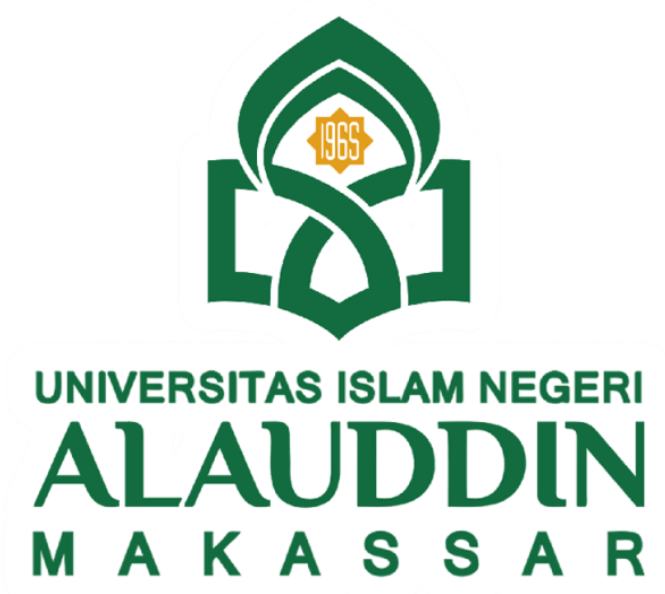

\author{
Disusun Oleh: \\ ANDI ASMA NINGSIH \\ 70200121111 \\ KESEHATAN MASYARAKAT D \\ PRODI KESEHATAN MASYARAKAT \\ FAKULTAS KEDOKTERAN DAN ILMU KESEHATAN \\ UIN ALAUDDIN MAKASSAR \\ 2021
}




\section{SEJARAH KESEHATAN MASYARAKAT}

\section{Sejarah Kesehatan Masyarakat Sebelum Ilmu Pengetahuan}

\section{Zaman Romawi dan Yunani Kuno}

Dari kebudayaan yang paling luas yakni Babylonia, Mesir, Yunani dan Roma telah tercatat bahwa manusia telah melakukan usaha untuk menanggulangi masalah-masalah kesehatan masyarakat dan penyakit. Telah ditemukan pula bahwa pada zaman tersebut tercatat dokumen-dokumen tertulis, bahkan peraturan-peraturan tertulis yang mengatur tentang pembuangan air limbah atau drainase pemukiman pembangunan kota, pengaturan air minum, dan sebagainya.

Pada zaman ini juga diperoleh catatan bahwa telah dibangun tempat pembuangan kotoran (latrin) umum, meskipun dibuatnya latrin tersebut bukan karena kesehatan. Dibangunnya latrin umum pada saat itu bukan karena tinja atau kotoran manusia dapat menularkan penyakit tetapi karena tinja menimbulkan bau yang tidak sedap. Masyarakat juga membuat sumur pada waktu itu dengan alasan bahwa minum air kali yang mengalir sudah kotor itu tidak enak, bukan karena minum air kali dapat menyebabkan penyakit.

Dari dokumen lain tercatat bahwa pada zaman Romawi kuno telah dikeluarkan suatu peraturan yang mengharuskan masyarakat mencatatkan pembangunan rumah, melaporkan adanya binatang-binatang yang berbahaya, dan binatang-binatang piaraan yang menimbulkan bau. Bahkan pada waktu itu telah ada keharusan pemerintah kerajaan unyuk melakukan supervise atau peninjauan kepada tempat-tempat minuman (public bar), warung makan, tempat-tempat prostitusi, dan sebagainya.

\section{Zaman Pertengahan}

Pada permulaan abad pertama sampai kira-kira abad ke-7 kesehatan masyarakat makin dirasakan kepentingannya karena berbagai macam penyakit menular mulai menyerang sebagian besar penduduk dan telah menjadi epidemi bahkan di beberapa tempat telah menjadi endemi.

Penyakit kolera telah tercatat sejak abad ke-7 menyebar dari Asia khususnya Timur Tengah dan Asia Selatan ke Afrika. India disebutkan sejak abad ke-7 tersebut telah menjadi pusat endemi kolera. Disamping itu lepra juga telah menyebar mulai dari Mesir ke Asia kecil dan Eropa melalui para emigran. 
Upaya-upaya untuk mengatasi epidemic dan endemic penyakit-penyakit tersebut, masyarakat mulai memperhatikan masalah lingkungan, terutama hygiene dan sanitasi lingkungan. Pembuangan kotoran manusia (latrin), pengusahaan air minum yang bersih, pembuangan sampah, ventilasi rumah telah tercatat menjadi bagian dari kehidupan masyarakat pada waktu itu.

Pada abad ke-14 mulai terjadi wabah pes yang paling dahsyat, di China dan India. Pada tahun 1340 tercatat 13.000 .000 orang meninggal karena wabah pes. Di India, Mesir, dan Gaza dilapporkan bahwa 13.000 orang meninggal tiap hari karena pes.

Menurut catatan, jumlah meninggal karena wabah pes di seluruh dunia waktu itu mencapai lebih dari 60.000.000 orang. Oleh sebab itu waktu itu disebut "The Black Death". Keadaan atau wabah-wabah penyakit menular ini berlangsung sampai menjelang abad ke-18. Disamping wabah pes, wabah kolera dan tipus masih berlangsung

Telah tercatat bahwa pada tahun 1603 lebih dari 1 diantara 6 orang meninggal, dan pada tahun 1663 sekitar 1 diantara 5 orang meninggal karena penyakit menular. Pada tahun 1759 ada 70.000 orang penduduk kepulauan Cyprus meninggal karena penyakit menular. Penyakit-penyakit lain yang menjadi wabah pada waktu itu antara lain difetri, tipus, disentri dan sebagainya.

Dari catatan-catatan tersebut dapat dilihat bahwa masalah kesehatan masyarakat khusunya penyebaran-penyebaran penyakit menular sudah begitu meluas dan dahsyat, namun upaya pemecahan masalah kesehatan masyarakat secara menyeluruh belum dilakukan oleh orang pada zamannya.

\section{Kesehatan Masyarakat Periode Ilmu Pengetahuan}

Bangkitnya ilmu pengetahuan pada akhir abad ke-18 dan awal abad ke-19 mempunyai dampak yang luas terhadap segala aspek kehidupan manusia, termasuk kesehatan. Kalau pada abad-abad sebelumnya masalah kesehatan khususnya penyakit hanya dilihat sebagai fenomena biologis dan pendekatan yang dilakukan hanya secara biologis yang sempit, maka mulai abad ke-19 masalah kesehatan adalah masalah yang kompleks. Oleh sebab itu pendekatan masalah kesehatan harus dilakukan secara komprehensif, multisektoral.

Disamping itu pada abad ilmu pengetahuan ini juga ditemukan berbagai macam penyebab penyakit dan vaksin sebagai pencegah penyakit. Louis Pasteur telah berhasil menemukan vaksin untuk mencegah penyakit cacar, Joseph Lister menemukan asam carbol 
(carbolic acid) untuk sterilisasi ruang operasi dan Wiliiam Marton menemukan ether sebagai anestesi pada waktu operasi.

Penyelidikan dan upaya-upaya kesehatan masyarakat secara ilmiah mulai dilakukan pada tahun 1832 di Inggris. Pada waktu itu sebagian besar rakyat Inggris terserang epidemic (wabah) kolera, terutama terjadi pada masyarakat yang tinggal di perkotaan yang miskin. Kemudian parlemen Inggris membentuk komisi untuk penyelidikan dan penanganan masalah pada wabah kolera ini.

Edwin Chadwic sebagai ketua komisi ini akhirnya melaporkan hasil penyelidikannya sebagai berikut: masyarakat hidup di suatu kondisi sanitasi yang jelek, sumur penduduk berdekatan dengan aliran air kotor dan pembuangan kotoran manusia. Air limbah yang mengalir terbuka tidak teratur, makanan yang dijual di pasar banyak dirubung lalat dan kecoa. Disamping itu ditemukan sebagian besar masyarakat miskin, bekerja rata-rata 14 jam per hari dengan gaji dibawah kebutuhan hidup. Sehingga sebagian masyarakat tidak mampu membeli makanan yang bergizi.

Berdasarkan laporan hasil penyelidikan Chadwic ini, akhirnya parlemen mengeluarkan undang-undang yang isinya mengatur upaya-upaya peningkatan kesehatan penduduk, termasuk sanitasi lingkuungan, sanitasi tempat-tempat kerja, pabrik dan sebagainya. Pada tahun 1848, Jon Simon diangkat oleh pemerintah Inggris untuk menangani masalah kesehatan penduduk (masyarakat).

Pada akhir abad ke-19 dan awal abad ke-20 mulai dikembangkan pendidikan untuk tenaga kesehatan yang profesional. Pada tahun 1893 John Hopkins, seorang pedagang wiski dari Baltimore Amerika mempelopori berdirinya Universitas dan didalamnya terdapat sekolah (Fakultas) Kedokteran.

Mulai tahun 1908 sekolah kedokteran mulai menyebar ke Eropa. Dari kurikulum sekolah-sekolah kedokteran tersebut terlihat bahwa kesehatan masyarakat sudah diperhatikan. Mulai tahun kedua para mahasiswa sudah mulai melakukan kegiatan penerapan ilmu di masyarakat.

Pada tahun 1855 pemerintah Amerika telah membentuk Departemen Kesehatan yang pertama kali. Fungsi departemen ini adalah menyelenggarakan pelayanan kesehatan bagi penduduk, termasuk perbaikan dan pengawasan sanitasi lingkungan. 


\section{SEJARAH PUSKESMAS}

Pusat Kesehatan Masyarakat, atau yang disingkat dan lebih dikenal di Indonesia dengan nama Puskesmas, adalah unit pelaksana teknis (UPT) dinas kesehatan kabupaten/kota yang bertanggungjawab menyelenggarakan pembangunan kesehatan di suatu wilayah kerja UPT. Sebagai unit fungsional pelayanan kesehatan terdepan dalam unit pelaksana teknis dinas kesehatan kabupaten/ kota, tugasnya adalah menyelenggarakan sebagian tugas teknis Dinas Kesehatan Pembangunan Kesehatan. Maksudnya adalah sebagai penyelenggara upaya kesehatan seperti melaksanakan upaya penyuluhan, pencegahan dan penanganan kasus-kasus penyakit di wilayah kerjanya, secara terpadu dan terkordinasi. Sementara pertanggung jawaban secara keseluruhan ada di Dinkes dan sebagian ada di Puskesmas.

Sejarah perkembangan kesehatan masyarakat di Indonesia dimulai sejak pemerintahan Belanda pada abad ke-16. Kesehatan masyarakat di Indonesia pada waktu itu dimulai dengan adanya upaya pemberantasan cacar dan kolera yang sangat ditakuti masyarakat pada waktu itu.

Kolera masuk di Indonesia tahun 1972 dan tahun 1937 terjadi wabah kolera eltor di Indonesia. Kemudian pada tahun 1948 cacar masuk ke Indonesia melalui Singapura dan muai berkembang di Indonesia. Sehingga berawal dari wabah kolera tersebut maka pemerintah Belanda pada waktu itu melakukan upaya-upaya kesehatan masyarakat.

Kemudian pada September 1959, wabah malaria masuk ke Malang. Dengan tekad di dada malaria ditargetkan terberantas pada tahun 1970.

Puskesmas telah menjadi tonggak periode perjalanan sejarah Dinas Kesehatan Kabupaten di Indonesia. Konsep Puskesmas sendiri diterapkan di Indonesia pada tahun 1969. Perihal diterapkannya konsep Puskesmas ini, pada awal berdirinya, sedikit sekali perhatian yang dicurahkan Pemerintah di Kabupaten pada pembangunan di bidang Kesehatan. Sebelum konsep Puskesmas diterapkan, dalam rangka memberikan pelayanan terhadap masyarakat maka dibangunlah Balai Pengobatan (BP), Balai Kesejahteraan Ibu dan Anak (BKIA), yang tersebar di kecamatan-kecamatan. Unit tersebut berdiri sendiri-sendiri tidak saling berhubungan dan langsung melaporkan kegiatannya kepada Kepala Dinas Kesehatan, umumnya unit tersebut dipimpin oleh seorang Mantri (perawat) senior yang pendidikannya bisa membantu perawat.

Sejalan dengan diterapkannya konsep Puskesmas di Indonesia tahun 1969, maka mulailah dibangun Puskesmas di beberapa wilayah yang dipimpin oleh seorang Dokter 
Wilayah (Dokwil) yang membawahi beberapa Kecamatan, sedang di tingkat kabupaten ada Dokter Kabupaten (Dukabu) yang membawahi Dokwil. Pelayanan kesehatan yang diberikan Puskesmas tersebut adalah pelayanan kesehatan menyeluruh (komprehensif) yang meliputi pelayanan: pengobatan (kuratif), upaya pencegahan (preventif), peningkatan kesehatan (promotif) dan pemulihan kesehatan (rehabilitatif).

Masalah-masalah kesehatan yang ditemukan juga sedemikian banyak, antara lain: Penyakit-penyakit menular (Cacar, Malaria, TBC) masih merajalela dengan incidence dan prevalence yang tinggi. Status gizi terutama pada golongan rawan anak-anak di bawah lima tahun dan ibu hamil atau menyusui masih belum memuaskan. Air minum yang sehat, pembuangan kotoran dan sanitasi perumahan yang sangat tidak memadai. Hal tersebut erat kaitannya dengan kemiskinan yang dicerminkan oleh rendahnya tingkat pendidikan, penghasilan perkapita, produksi perkapita dan konsumsi perkapita (termasuk konsumsi dalam bidang sanitasi, gizi dan pelayanan kesehatan).

Selain hal tersebut masalah ketenagaan, khususnya dokter, perawat gigi, nutrisionis, jumlahnya juga masih terbatas. Disadari bahwa tanpa partisipasi masyarakat secara memadai, tidaklah mungkin keinginan atau tuntutan (demand) masyarakat yang semakin meningkat di bidang kesehatan. Untuk itu pada tahun 1976 dikembangkanlah konsep Pembangunan Kesehatan.

\section{Kesehatan dasar BASIC SIX atau 6 program pokok puskesmas yaitu:}

1. Promosi kesehatan.

2. Kesehatan lingkungan.

3. Pencegahan Pemberantasan Penyakit Menular

4. Kesehatan Keluarga dan Reproduksi

5. Perbaikan Gizi masyarakat

6. Penyembuhan Penyakit dan Pelayanan Kesehatan

\section{Promosi Kesehatan}

A. Pengertian 
Penyuluhan Kesehatan Masyarakat adalah upaya untuk memberikan pengalaman belajar atau menciptakan kondisi bagi perorangan, kelompok dan masyarakat, dalam berbagai tatanan, dengan membuka jalur komunikasi, menyediakan informasi, dan melakukan edukasi, untuk meningkatkan pengetahuan, sikap dan perilaku, dengan melakukan advokasi, pembinaan suasana dan gerakan pemberdayaan masyarakat untuk mengenali, menjaga/memelihara, meningkatkan dan melindungi kesehatannya.

B. Tujuan

Tercapainya perubahan prilaku individu, keluarga dan masyarakat dalam membina dan memelihara perilaku sehat, serta berperan aktif dalam upaya mewujudkan derajat kesehatan yang optimal.

C. Sasaran

a. Pelaksanaan posyandu dan Pembinaan kader

b. Penyuluhan Kesehatan individu dan kelompok

Contoh: penyuluhan PHBS, vitamin A, narkoba, P2M, HIV, malaria, diare, penggunaan jamkesmas.

\section{Kesehatan Lingkungan}

\section{A. Pengertian}

Bahaya potensial terhadap kesehatan yang diakibatkan oleh lingkungan dapat bersifat fisik, kimia maupun biologi. Sejalan dengan kebijaksanaan'Paradigma Sehat' yang mengutamakan upaya-upaya yang bersifat promotif, preventif dan protektif. Maka upaya kesehatan lingkungan sangat penting.

B. Tujuan

Kegiatan peningkatan kesehatan lingkungan bertujuan terwujudnya kualitas lingkungan yang lebih sehat agar dapat melindungi masyarakat dari segala kemungkinan resiko kejadian yang dapat menimbulkan gangguan dan bahaya kesehatan menuju derajat kesehatankeluarga dan masyarakat yang lebih baik.

C. Kegiatan

Kegiatan-kegiatan utama kesehatan lingkungan yang harus dilakukan Puskesmas meliputi:

1. Penyehatan air

2. Penyehatan makanan dan minuman

3. Pengawasan pembuangan kotoran manusia

4. Pengawasan dan pembuangan sampah dan limbah

5. Penyehatan pemukiman 
6. Pengawasan sanitasi tempat umum

7. Pengamanan polusi industry

8. Pengamanan pestisida

9. Klinik sanitasi

\section{Pencegahan Pemberantasan Penyakit Menular}

A. Pengertian

Penyakit Menular adalah penyakit yang disebabkan oleh agent infeksi atau toksinnya, yang beraasal dari sumber penularan atau reservoir, yang ditularkan/ditansmisikan kepada pejamu (host) yang rentan.

- Cara Penularan Penyakit Menular

Dikenal beberapa cara penularan penyakit menular yaitu:

a. Penularan secara kontak

b. Penularan melalui vehicle seperti melalui makanan dan minuman yang tercemar

c. Penularan melalui vektor

d. Penularan melalui suntikan, transfusi, tindik dan tato.

- Surveilans Epidemiologi Penyakit Menular

adalah suatu kegiatan pengumpulan data/informasi melalui pengamatan terhadap kesakitan/kematian dan penyebarannya serta faktor-faktor yang mempengaruhinya secar sistematik, terus menerus dengan tujuan untuk perencanaan suatu program, mengevaluasi hasil program, dan sistem kewaspadaan dini.

B. Program Pemberantasan Penyakit Menular

a. Program imunisasi

b. Program TB paru dengan kegiatan penemuan penderita TBC

c. Program malaria dengan angka insiden malaria (AMI)

d. Program ISPA dengan frekuensi penemuan dan penaggulangan pneumonia

e. Program diare meliputi frekuensi penanggulangan diare

f. Program rabies

g. Program Surveilans

h. Pemberantasan P2B2 demam berdarah

\section{Kesehatan Keluarga dan Reproduksi}

A. Pengertian 
Kesehatan Keluarga adalah wujud keluarga sehat, kecil bahagia dan sejahtra dari suami istri,anak dan anggota keluarga lainnya (UU RI no 23 th 1992).

Kesehatan Reproduksi adalah kesejahteraan fisik, mental dan sosial yang utuh. Bukan hanya bebas dari penyakit dan kecacatan, dalam segala aspek yang berhubungan dengan sistemreproduksi, fungsi serta prosesnya (WHO).

B. Tujuan

Meningkatkan kesadaran kemandirian wanita dan keluarganya dalam mengatur biologik keluarga termasuk fungsi reproduksinya serta berperan serta aktif dalam mencegah dan menyelesaikan masalah kesehatan keluarga serta meningkatkan kualitas hidup keluarga.

Pelayanan reproduksi adalah:

1. Kesehatan ibu dan anak

2. Kesehatan anak usia sekolah

3. Kesehatan remaja, termasuk pencegahan serta penanganan PMS (PenyakitMenular akibat Hubungan Seks, HIV/AIDS)

4. Keluarga berencana

5. Kesehatan usia lanjut (Program Pengembangan Puskesmas)

Indikator keberhasilan program di wilayah kerja dinilai dari:

1. Angka kematian bayi

2. Angka kematian ibu

3. Presentase ibu hamil yang mempunyai berat badan dan tinggi yang normal

4. Presentase ibu hamil dengan anemia

5. Presentase balita dengan berat badan dan tinggi sesuai umur

\section{Perbaikan Gizi Masyarakat}

A. Pengertian

Adalah kegiatan untuk mengupayakan peningkatan status gizi masyarakat dengan pengelolaan terkoordinasi dari berbagai profesi kesehatan serta dukungan peran serta aktif masyarakat.

B. Program

Upaya Perbaikan Gizi Puskesmas meliputi:

1. Upaya Perbaikan Gizi Keluarga (UPGK)

2. Upaya Perbaikan Gizi Institusi (UPGI) 
3. Upaya Penanggulangan Kelainan Gizi Yang Terdiri Dari:

A. Pencegahan Dan Penanggulangan Gangguan Akibat Kekurangan Yodium (GAKY)

B. Pencegahan Dan Penanggulangan Anemia Besi (AGB)

C. Pencegahan Dan Penanggulangan Kurang Kalori Energi Protein (KEP) Dan KurangEnergi Kronis (KEK)

D. Pencegahan Dan Penaggulangan Kekurangan Vitamin A (KVA)

E. Pencegahan Dan Penaggulangan Masalah Kekurangan Gizi Mikro Lain

F. Pencegahan Dan Penaggulangan Masalah Gizi Lebih

4. Sistem Kewaspadaan Pangan Dan Gizi (SKPG)

C. Sasaran

Sasaran upaya perbaikan gizi adalah kelompok-kelompok yang beresiko menderita kelainan gizi antara lain:

1. Bayi, anak balita, anak pra sekolah dan anak usia sekolah

2. Wanita Usia Subur (WUS) termasuk calon pengantin (cantin), ibu hamil, ibu nifas, ibu menyusui, dan usia lanjut (usila)

3. Semua penduduk rawan gizi (endemik)

4. Semua anak dan dewasa mempunyai masalah gizi

5. Pekerja penghasilan rendah.

\section{Penyembuhan Penyakit dan Pelayanan Kesehatan}
A. Pelayanan Medik Rawat Jalan
B. Pelayanan Kedaruratan Medik
C. Pelayanan Kesehatan Gigi dan Mulut

Tujuan Pembangunan Millennium:

Millennium Development Goals (MDGs) atau dalam bahasa Indonesia diterjemahkan menjadi Tujuan Pembangunan Milenium, adalah sebuah paradigma pembangunan global,dideklarasikan Konperensi Tingkat Tinggi Milenium oleh 189 negara anggota Perserikatan Bangsa Bangsa (PBB) di New York pada bulan September 2000. Dasar hukum dikeluarkannya deklarasi MDGs adalah Resolusi Majelis Umum Perserikatan Bangsa-Bangsa Nomor 55/2 Tangga 18 September 2000, (A/Ris/55/2 Tujuan Pembangunan Millenium PBB). Semua negara yang hadir dalam pertemuan tersebut berkomitmen tuntuk mengintegrasikan MDGs sebagai bagian dari program pembangunan nasional dalam upaya menangani penyelesaian terkait dengan isu-isu yang sangat mendasar tentang pemenuhan hak asasi dan 
kebebasan manusia, perdamaian, keamanan, dan pembangunan. Deklarasi ini merupakan kesepakatan anggota PBB mengenai sebuah paket arah pembangunan global yang dirumuskan dalam beberapa tujuan yaitu:

1. Menanggulangi Kemiskinan dan Kelaparan,

2. Mencapai Pendidikan Dasar untuk semua,

3. Mendorong Kesetaraan Gender, dan Pemberdayaan Perempuan,

4. Menurunkan Angka Kematian Anak,

5. Meningkatkan Kesehatan Ibu,

6. Memerangi HIV/AIDs, Malaria dan Penyakit Menular Lainnya,

7. Memastikan Kelestarian Lingkungan Hidup, dan

8. Membangun Kemitraan Global untuk Pembangunan.

Setiap tujuan menetapkan satu atau lebih target serta masing-asing sejumlah indikator yang akan diukur tingkat pencapaiannya atau kemajuannya pada tenggat waktu hinggatahun 2015. Secara global ditetapkan 18 target dan 48 indikator. Meskipun secara glonal ditetapkan 48 indikator namun implementasinya tergantung pada setiap Negara disesuaikan dengan kebutuhan pembangunan dan ketersediaan data yang digunakan untuk mengatur tingkat kemajuannya. Indikator global tersebut bersifat fleksibel bagisetiap negara.

Deklarasi MDGs merupakan hasil perjuangan dan kesepakatan bersama antara negara-negara berkembang dan maju. Negera-negara berkembang berkewajiban untuk melaksanakannya, termasuk salah satunya Indonesia dimana kegiatan MDGs di Indonesiamencakup pelaksanaan kegiatan monitoring MDGs. Sedangkan negara-negara maju berkewajiban mendukung dan memberikan bantuan terhadap upaya keberhasilan setiap tujuan dan target MDGs. Semua upaya dalam kegiatan MDG's ini diharapkan dapat tercapai pada tahun 2015 mendatang.

Dokter umum merupakan ujung tombak pelayanan kesehatan. Terutamaupaya dalam pemberian layanan promotif, preventif, ckuratif dan rehabilitative. Ciri dokter layanan primer sendiri adalah: (Goroll, 2006) Menjadi kontak pertama dengan pasien dan memberi pembinaan berkelanjutan (continuing care) Membuat diagnosis medis dan penangannnya, Membuat diagnosis psikologis dan penangannya, Memberi dukungan personal bagi setiap pasien dengan berbagai latar belakang dan berbagai stadium penyakit. Mengkomunikasikan informasi tentang pencegahan, diagnosis, pengobatan, dan prognosis, dan Melakukan pencegahan dan pengendalian penyakit kronik dan kecacatan melalui penilaian risiko, pendidikan kesehatan, deteksi dini penyakit, terapi preventif, dan perubahan perilaku. 
Dokter penyelenggara pelayanan kesehatan tingkat primer termasuk Dokter (Praktik Umum) yang praktik pribadi Dokter Keluarga yang praktik pribadi Dokter layanan primer lainnya termasuk: Dokter Praktik Umum yang praktik solo Dokter (praktik umum) praktik bersama Dokter perusahaan Dokter bandara Dokter pelabuhan Dokter kampus Dokter pesantren Dokter haji Dokter Puskesmas Dokter yang bekerja diunit gawat darurat Dokter yang bekerja di Poliklinik Umum RS Dokter Praktik Umumyang bekerja di bagian pelayanan khusus misalnya Unit Hemodialisis, PMI, dsb. 


\section{TINJAUAN PUSTAKA}

\subsubsection{Definisi Pusat Kesehatan Masyarakat}

Pusat Kesehatan Masyarakat (Puskesmas) merupakan salah satu fasilitas pelayanan kesehatan yang menyelenggarakan upaya kesehatan masyarakat dan upaya kesehatan perseorangan tingkat pertama. Pelayanan kesehatan yang diselenggarakan di puskesmas lebih mengutamakan upaya promotif dan preventif, untuk mencapai derajat kesehatan masyarakat yang setinggi-tingginya di wilayah kerja puskesmas tersebut (Kementerian Kesehatan Republik Indonesia, 2014).

Puskesmas merupakan salah satu sarana pelayanan kesehatan yang memiliki peran penting dalam memberikan pelayanan kesehatan kepada masyarakat. Selain itu, puskesmas adalah salah satu fasilitas pelayanan kesehatan tingkat pertama yang menjadi tolak ukur dari pembangunan kesehatan. Puskesmas memiliki tugas untuk melaksanakan kebijakan kesehatan untuk dapat mencapai tujuan pembangunan kesehatan di wilayah kerjanya dalam rangka mendukung terwujudnya kecamatan sehat. Dalam melaksanakan tugas untuk mewujudkan kecamatan sehat, puskesmas menyelenggarakan fungsi penyelenggaraan UKM (Upaya kesehatan Masyarakat) tingkat pertama, dan penyelenggaraan UKP (Upaya Kesehatan Perorangan) tingkat pertama di wilayah kerjanya (Kementerian Kesehatan Republik Indonesia, 2014).

\subsubsection{Organisasi Puskesmas}

Sesuai dengan ketentuan Peraturan Menteri Kesehatan Republik Indonesia Nomor 75 Tahun 2014 Tentang Pusat Kesehatan Masyarakat, puskesmas atau pusat kesehatan masyarakat merupakan unit pelaksana teknis dari dinas kesehatan kabupaten/kota. Puskesmas dipimpin oleh Kepala Puskesmas yang bertanggungjawab atas seluruh kegiatan di puskesmas. Organisasi puskesmas disusun oleh dinas kesehatan kabupaten/kota berdasarkan kategori, upaya kesehatan dan beban kerja puskesmas. Organisasi puskesmas minimal terdiri dari:

1. Kepala Puskesmas

2. Kepala sub bagian tata usaha

3. Penanggung jawab UKM (Upaya Kesehatan Masyarakat) dan Keperawatan Kesehatan Masyarakat 
4. Penanggung jawab UKP (Upaya Kesehatan Perorangan), kefarmasian dan Laboratorium

5. Penanggungjawab jaringan pelayanan puskesmas dan jejaring fasilitas pelayanan kesehatan.

\subsubsection{Upaya Kesehatan Perorangan di Puskesmas}

Upaya kesehatan perorangan tingkat pertama di puskemas dilaksanakan melalui beberapa kegiatan antara lain :

1. Rawat jalan

2. Pelayanan gawat darurat

3. Pelayanan satu hari (one day care)

4. Home care

5. Rawat inap berdasarkan pertimbangan kebutuhan pelayanan kesehatan.

Upaya kesehatan perorangan tingkat pertama ini dilaksanakan sesuai dengan standar prosedur operasional dan standar pelayanan (Kementerian Kesehatan Republik Indonesia, 2014). Berdasarkan Peraturan Menteri Kesehatan RI Nomor 75 Tahun 2014 mengenai puskesmas, sumber daya manusia yang diperlukan untuk menyelenggarakan upaya kesehatan perorangan di puskesmas antara lain terdiri dari dokter atau dokter layanan primer, dokter gigi, perawat, bidan, ahli teknologi laboratorium medis, serta tenaga kefarmasian.

\subsubsection{Administrasi dan Manajemen Puskesmas}

Administrasi merupakan proses penyelenggaraan kerja yang dilakukan bersama-sama sehingga dapat mencapai tujuan yang telah ditetapkan. Untuk dapat mewujudkan penyelenggaraan administrasi diperlukan pelaksanaan fungsi-fungsi 12 manajemen yang terdiri dari fungsi perencanaan, pengorganisasian, pelaksanaan, dan pengawasan (Kementerian Kesehatan Republik Indonesia, 2014).

Manajemen puskesmas merupakan rangkaian kegiatan yang bekerja secara sistematis untuk menghasilkan luaran puskesmas yang efektif dan efisien. Rangkaian kegiatan sistematis yang dilaksanakan oleh puskesmas tersebut membentuk fungsifungsi manajemen pusksesmas yang terdiri dari perencanaan, pelaksanaan dan pengendalian, serta pengawasan dan pertanggungjawaban. Seluruh fungsi manajemen puskesmas tersebut wajib dilaksanakan secara terkait dan berkesinambungan (Kementerian Kesehatan Republik Indonesia 2004). Perencanaan merupakan fungsi manajemen puskesmas yang dilakukan sebagai langkah awal 
sebelum melaksanakan kegiatan. Perencanaan puskesmas meliputi kegiatan merumuskan tujuan puskesmas sampai dengan kegiatan merumuskan alternatif kegiatan.

Perencanaan puskesmas merupakan hal yang sangat penting karena tanpa adanya perencanaan maka tidak akan ada kejelasan bagi kegiatan yang akan dilaksanakan oleh staf untuk mencapai tujuan puskesmas. Perencanaan di tingkat puskesmas dilakukan dengan membuat rencana usulan kegiatan, kemudian mengajukan usulan kegiatan yang direncanakan ke dinas kesehatan untuk mendapatkan persetujuan, dan kemudian menyusun rencana pelaksanaan kegiatan (RPK) (Artini, 2015). 


\section{DAFTAR PUSTAKA}

Indonesia, P. (2012, April 13). Pelangi Indonesia. Retrieved November 13, 2021, from pelangi-1ndonesia.blogspot.com: https://pelangi-1ndonesia.blogspot.com/2013/05/sejarahpuskesmas-di-indonesia-dan-pkmd.html

Notoatmodjo, P. D. (2013). Sejarah Perkembangan Ilmu Kesehatan Masyarakat. 